\title{
Levels of heavy metals in urine samples of school children from selected industrial and non-industrial areas in Dar es Salaam, Tanzania
}

\author{
John AM Mahugija ${ }^{1}$, Zainab S Kasenya ${ }^{2}$, Kessy F Kilulya ${ }^{1}$
}

1. Chemistry Department, University of Dar es Salaam, P. O. Box 35061 Dar es Salaam, Tanzania.

2. Faculty of Science, Muslim University of Morogoro, P. O. Box 1031 Morogoro, Tanzania.

\begin{abstract}
Objectives: The levels of lead, zinc, iron, copper and cadmium metals in the urine samples of selected school children in industrial and non-industrial areas in Dar es Salaam were investigated.

Methods: Urine samples were collected from 120 children in industrial areas and 120 children in non-industrial areas then digested in concentrated acids and analysed using atomic absorption spectrophotometry (AAS).

Results: The concentrations of the heavy metals in the urine samples ranged from below detection limit/non-detectable (ND) to $1.92 \mathrm{mg} / \mathrm{L}$ for lead, ND to $2.55 \mathrm{mg} / \mathrm{L}$ for zinc, ND to $8.98 \mathrm{mg} / \mathrm{L}$ for iron and ND to $0.05 \mathrm{mg} / \mathrm{L}$ for copper. Cadmium was not detected. Significant differences were found between the concentrations of heavy metals in urine of pupils from the industrial areas and those from non-industrial areas. The mean concentrations of lead and copper in samples from industrial areas were significantly higher than those found in non-industrial areas $(\mathrm{p}<0.002)$, while the mean concentrations of zinc and iron found in samples from non-industrial areas were significantly higher than those found in industrial areas $(\mathrm{p}<0.0001)$.

Conclusion: The contamination levels were generally high in samples from both areas indicating exposure from various sources. The findings indicate public health risks.

Keywords: Heavy metals, children urine, industrial areas, non-industrial areas, Tanzania.

DOI: https://dx.doi.org/10.4314/ahs.v18i4.44

Cite as: Mabugija JAM, Kasenya ZS, Kilulya KF. Levels of heavy metals in urine samples of school children from selected industrial and non-industrial areas in Dar es Salaam, Tanzania. Afri Health Sci. 2018;18(4): 1226-1235. https:/ / dx.doi.org/10.4314/ abs.v18i4.44
\end{abstract}

\section{Introduction}

The determination of heavy metals in urine has been the subject of continuous interest in the biomedical and environmental sciences ${ }^{1}$. Urine plays an important role in metal analysis due to its simple mode of collection, storage and sample preparation; hence it is widely used as an attractive matrix for estimation of exposure ${ }^{2}$. Analysis
Corresponding author:
John A. M. Mahugija, Chemistry Department, University of Dar es Salaam,
P. O. Box 35061
Dar es Salaam, Tanzania.
E-mail addresses: mahugija@udsm.ac.tz; johnmahugija@yahoo.com

of urine samples reflects the total body intake of certain elements better than other biological fluids ${ }^{3}$. School children differ in their lifestyles, habits and metabolism of toxicants. Children are easily exposed to the toxic substances such as heavy metals because their body systems are still developing ${ }^{4,5}$. In fact, children are known to absorb metals more readily than adults and are particularly sensitive for biological and developmental reasons ${ }^{6}$. There is a definite paucity of data concerning children. These are some of the specific causes for concerns.

Heavy metals are found naturally in the earth's crust and they are also released into the environment through human activities. Their widespread uses have resulted in extensive environmental contamination, human exposure and significant public health problems in many parts of the world. The important sources of heavy metals in

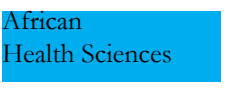

(C) 2018 Mahugija et al. Licensee African Health Sciences. This is an Open Access article distributed under the terms of the Creative commons Attribution License (https://creativecommons.org/licenses/BY/4.0), which permits unrestricted use, distribution, and reproduction in any medium, provided the original work is properly cited. 
the environment include weathering of the earth's crust, soil erosion, mining, smelting, industrial effluents, urban runoff, sewage discharge, pest or disease control agents applied to crops, manufacturing and recycling activities, paints, leaded gasoline, batteries, ceramic glazes, jewellery, toys, cosmetics, traditional medicines, drinking water delivered through metal pipes and many others ${ }^{7}$. Human beings are exposed to the heavy metals mainly through inhalation of dusts in air or particles generated by burning materials containing metals, and ingestion of metal-contaminated water, food, soil, etc. Once heavy metals enter the body, they are distributed to organs such as the brain, kidneys, liver and bones. The body stores the metals in the teeth, bones and other tissues where they accumulate over time, while some amounts of the metals are removed from the body through the excretory systems ${ }^{7}$.

Heavy metals cause health effects to human beings, including children. The toxic effects of the heavy metals vary depending on the type of the metal, dose or concentration, duration of exposure and other factors. The toxic effects of some heavy metals are briefly presented hereunder. The toxic effects of lead in children include profound and permanent adverse health effects on the development of the brain and nervous system ${ }^{8}$. At high levels of exposure, lead attacks the brain and central nervous system and cause mental retardation, behavioural disorders, convulsions, coma and even death. At low levels of exposure, lead can produce a variety of damages in various body systems including affecting children's brain development resulting in reduced intelligence quotient (IQ), behavioural changes such as increased anti-social behaviour, reduced attention span and reduced educational achievement. Lead exposure also causes toxicity to the reproductive organs, immunotoxicity, anaemia, renal impairment and hypertension. It is known that, as lead exposure increases, the range and severity of the symptoms and effects also increase. Blood lead concentrations as low as $5 \mu \mathrm{g} / \mathrm{dL}$ may be associated with decreased intelligence in children, behavioural difficulties, and learning problems ${ }^{8}$. Cadmium accumulation in the body causes effects such as nephrotoxicity and osteoporosis. Cadmium exposure is also associated with lung cancer in adulthood. Cadmium affects the hypothalamus-pituitary axis and this may lead to disorders of the endocrine and immune system. In school age children, urinary cadmium levels were associated with immunosuppression ${ }^{9}$. Oral intake of ex- tremely high doses of zinc (above $300 \mathrm{mg} \mathrm{Zn}$ /day) may cause nausea, vomiting, pain, cramps and diarrhoea ${ }^{10}$. Copper is essential for good health. However, exposure to high doses of copper can be harmful in children and adults. Long-term exposure to copper causes irritation to the eyes, mouth and nose, and can cause vomiting, dizziness, nausea, diarrhoea, headaches, stomach cramps, liver and kidney damage and even death ${ }^{11}$. Toxic effects of iron can be caused by intake of a large excess of the metal and usually are acute effects such as stomach pain, nausea, vomiting, diarrhoea, bloody vomiting, bloody stool, dehydration and lethargy due to damage to internal organs, particularly the brain and the liver ${ }^{12}$.

Studies on heavy metals contamination in Tanzania have revealed high concentrations of heavy metals in water, sediments, soil and food substances including vegetables ${ }^{13,14,15}$. These findings indicated high exposure risks to human beings and other organisms. However, no study had been conducted to determine the levels of heavy metals in human samples such as urine in Tanzania. Thus, this study was aimed at determining the levels of lead, cadmium, zinc, iron and copper in human urine. These metals were selected because of the availability of potential sources in the study areas and their importance in terms of potential adverse health effects to human beings.

\section{Materials and methods Study areas}

The study was conducted at Chang'ombe in Temeke district, Mtakuja (Vingunguti) in Ilala district and Bunju in Kinondoni district in Dar es Salaam, Tanzania. Chang'ombe and Mtakuja (Vingunguti) represented the industrial areas whereas Bunju represented non-industrial areas. Mtakuja is located about $6 \mathrm{~km}$ from the city centre and is close to the Vingunguti industrial area. Chang'ombe is located near the industrial areas in Temeke district. Manufacturing and processing industries are dominant in dominant in Chang'ombe, Keko, Mbagala, Temeke and Vijibweni areas. Service industries which include garages and warehouses are situated in many parts of the district including at Kurasini area and along the Mandela highway and part of Kilwa road. Bunju is located in Kinondoni district along Bagamoyo road and is about $36 \mathrm{~km}$ from the city centre, which places this area within the peri-urban zone. The study areas are shown in Figure 1. 


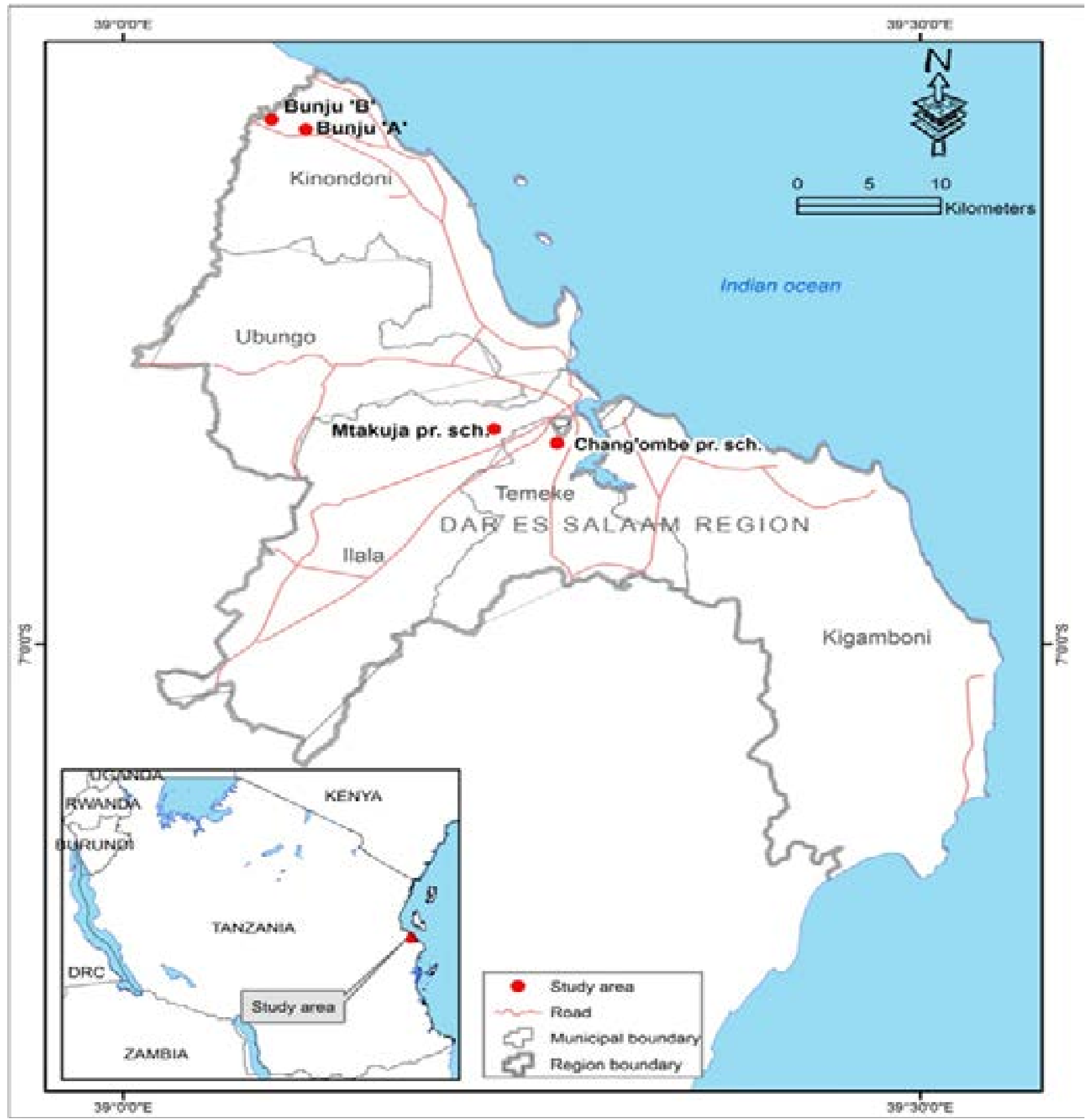

Figure 1. Map showing the study areas in Dar es Salaam.

\section{Ethical issues}

This study was approved by the Ethics Commission of the National Institute for Medical Research (NIMR) of Tanzania (Ref. No. NIMR/HQ/R.8a/Vol. IX/2263) and the Research Ethics Committee of the University of Dar es Salaam. The participants and their teachers/parents were duly informed of the objectives of the study before the samples were collected. Participation in the study was purely based on the willingness of the individuals.
Participating pupils were given unique number codes and no names were used in the records to ensure that they remain anonymous.

\section{Sampling and storage}

Children from two primary schools in industrial areas (Chang'ombe and Mtakuja schools) and two primary schools in non-industrial areas (Bunju A and Bunju B) were the population of the study. School children aged African Health Sciences Vol 18 Issue 4, December, 2018 
5 to 14 years and living in the vicinity of the study areas were eligible for the study. During sampling in the industrial areas, pupils who live in non-industrial areas but school in the industrial areas were excluded from the study and for sampling in the non-industrial areas; pupils who live in industrial areas but school in the non-industrial areas were excluded. Each of the schools provided a total of 60 participants (carefully selected based on classes (grades), age, and gender). The study had a sample size of 240 children that included 120 children from schools in industrial areas and 120 children from non-industrial areas. A spot morning urine sample was collected from each participant in a $60-\mathrm{mL}$ sterile polyethylene bottle. The samples were packed into a plastic container and immediately transferred to the laboratory and stored in a refrigerator prior to preparation for analysis.

\section{Laboratory sample pre-treatment}

The treatment procedures described by Adotey et al. ${ }^{16}$ were adopted with minor modifications. During treatment, a urine sample $(20 \mathrm{~mL})$ was placed into a $150-\mathrm{mL}$ beaker and $15.8 \mathrm{M}$ nitric acid $(10 \mathrm{~mL})$ was added. The beaker was covered with a watch glass, heated on a hot plate for 30 minutes followed by cooling to room temperature. Concentrated nitric acid $(15.8 \mathrm{M}, 10 \mathrm{~mL})$ was added again followed by heating until the solution was reduced to about $5 \mathrm{~mL}$. It was allowed to cool, and then, distilled water $(2 \mathrm{~mL})$ and $30 \%$ hydrogen peroxide $(10$ $\mathrm{mL}$ ) were added, the beaker was covered with a watch glass and heated on a hot plate until a clear solution was obtained. It was then allowed to cool and thereafter concentrated hydrochloric acid $(10 \mathrm{~mL})$ and distilled water $(10 \mathrm{~mL})$ were added and the mixture heated for $15 \mathrm{~min}$ utes. The samples were diluted to $20 \mathrm{~mL}$ with distilled water after cooling.

\section{Determination of heavy metals}

The determination of the heavy metals in the urine samples was conducted by atomic absorption spectrophotometry (AAS) at the Chemistry Department, University of Dar es Salaam. A Thermo Scientific AAS Model iCE 3000 was used for quantitative analysis of the heavy metals in the samples. The quantitative analysis involved measuring the absorbance of each analyte in the samples and standard solutions. Lead, cadmium, copper, iron and zinc absorbances were measured at wavelengths of 283.3 $\mathrm{nm}, 228.8 \mathrm{~nm}, 324.7 \mathrm{~nm}, 248.3 \mathrm{~nm}$ and $213.9 \mathrm{~nm}$, respec- tively ${ }^{17}$. A series of calibration standards were run in the AAS and the calibration curves were used for calculation of the concentrations of the metals. The blank readings were subtracted from the sample readings.

\section{Quality assurance/quality control}

Recovery tests were done using selected urine samples and distilled water for quality assurance procedures. The recovery samples (20 mL each) were spiked with standard solutions of the metals for recovery tests and processed using the same procedures used during the treatment of the urine samples. When a urine sample was used for determination of recoveries, first the concentrations of the metals in it were established before spiking. Then, after spiking, the concentrations were determined and the percentage recoveries were calculated by subtraction as shown in the following formula:

$\%$ Recovery $=\frac{\mathrm{C}_{\text {spiked sample }}-\mathrm{C}_{\text {unspiked sample }}}{\mathrm{C}_{\text {added }}} \times 100$

The recovery tests were repeated for each metal and the results obtained were used to calculate the accuracy and precision of the analytical method used. The accuracy (recoveries of $95 \%$ to $109 \%$ ) and precision (relative standard deviations of $<5 \%$ ) were suitable. Four blank samples were prepared in each batch using distilled water $(20 \mathrm{~mL})$ which were digested with concentrated hydrochloric and nitric acids, treated and analysed in the same way as the samples to check for background contamination caused by the reagents used. The detection limits of the metals were established based on a 3:1 signal to noise ratio and they ranged from 0.001 to $0.005 \mathrm{mg} / \mathrm{L}$. Calibration standards were run at the beginning of the analysis and used for the quantification of the metals. The standards were also run after every few samples to check the performance of the instrument in terms of its detection capability, sensitivity and linearity. Two readings were taken per run of each sample or recovery sample or blank sample.

\section{Data analysis}

Data analyses were performed using the statistical package for social sciences (SPSS-version 21). Comparison of the heavy metal concentrations in urine samples between sampling sites in industrial areas and non-industrial areas was done by using unpaired t-test. The level of significance was set at $\mathrm{p}=0.05$ (95\% confidence level). 


\section{Results}

Concentrations of trace metal elements in urine samples

Table 1 presents the concentrations of the trace metals (lead, zinc, iron and copper) detected in the urine samples, while cadmium was not detected in all the samples. The concentrations of the heavy metals in the urine samples of the school pupils ranged from below detection limit or non- detectable (ND) to $1.92 \mathrm{mg} / \mathrm{L}$ for lead, ND to $2.55 \mathrm{mg} / \mathrm{L}$ for zinc, ND to $8.98 \mathrm{mg} / \mathrm{L}$ for iron, and $\mathrm{ND}$ to $0.05 \mathrm{mg} / \mathrm{L}$ for copper. Lead, zinc, iron and copper were detected in $78.8 \%, 98.75 \%, 99.58 \%$ and $22.92 \%$ of the urine samples, respectively. The overall mean concentrations of the metals in the urine samples from all the study areas ranged from 0.14 to $0.80 \mathrm{mg} / \mathrm{L}$ for lead, 0.55 to $0.93 \mathrm{mg} / \mathrm{L}$ for zinc, 1.27 to $3.01 \mathrm{mg} / \mathrm{L}$ for iron and up to $0.03 \mathrm{mg} / \mathrm{L}$ for copper.

Table 1. Concentrations of the heavy metals in pupils' urine samples from the selected schools.

\begin{tabular}{|c|c|c|c|c|c|c|}
\hline Metal & Parameter & $\begin{array}{l}\text { Випји } A \\
(N=60)\end{array}$ & $\begin{array}{l}\text { Випји B } \\
(N=60)\end{array}$ & $\begin{array}{l}\text { Chang'ombe } \\
(N=60)\end{array}$ & $\begin{array}{l}\text { Mtakija } \\
(N=60)\end{array}$ & $\begin{array}{l}\text { Overall/All } \\
(N=240)\end{array}$ \\
\hline \multirow[t]{3}{*}{ Lead } & Range (mg/L) & ND-1.92 & ND-0.68 & ND-1.51 & ND-0.83 & ND-1.92 \\
\hline & Mean $\pm \mathrm{SD}(\mathrm{mg} / \mathrm{L})$ & $0.79 \pm 0.51$ & $0.14 \pm 0.21$ & $0.80 \pm 0.47$ & $0.48 \pm 0.14$ & $0.55 \pm 0.46$ \\
\hline & Detection frequency $(\%)$ & 83.3 & 50 & 81.7 & 98.3 & 78.8 \\
\hline \multirow[t]{3}{*}{ Zinc } & Range (mg/L) & ND-2.55 & $0.07-1.82$ & ND-1.32 & ND-1.68 & ND-2.55 \\
\hline & Mean $\pm \mathrm{SD}(\mathrm{mg} / \mathrm{L})$ & $0.93 \pm 0.42$ & $0.72 \pm 0.44$ & $0.56 \pm 0.24$ & $0.55 \pm 0.25$ & $0.69 \pm 0.38$ \\
\hline & Detection frequency $(\%)$ & 98.3 & 100 & 98.3 & 98.3 & 98.8 \\
\hline \multirow[t]{3}{*}{ Iron } & Range (mg/L) & $0.84-8.98$ & $0.56-4.01$ & $1.2-3.23$ & ND-2.08 & ND-8.98 \\
\hline & Mean $\pm \mathrm{SD}(\mathrm{mg} / \mathrm{L})$ & $3.01 \pm 1.05$ & $1.89 \pm 0.83$ & $2.23 \pm 0.49$ & $1.27 \pm 0.39$ & $2.10 \pm 0.97$ \\
\hline & Detection frequency $(\%)$ & 100 & 100 & 100 & 98.3 & 99.6 \\
\hline \multirow[t]{3}{*}{ Copper } & Range (mg/L) & ND & ND & ND-0.05 & ND & ND-0.05 \\
\hline & Mean \pm SD $(\mathrm{mg} / \mathrm{L})$ & ND & ND & $0.03 \pm 0.01$ & ND & $0.01 \pm 0.02$ \\
\hline & Detection frequency $(\%)$ & 0 & 0 & 91.7 & 0 & 22.9 \\
\hline Cadmium & Range, Mean & ND & ND & ND & ND & ND \\
\hline
\end{tabular}

$\mathrm{N}=$ Number of samples, ND = Non-detectable (below detection limit), SD = Standard deviation

The mean concentrations of the heavy metals in the urine samples of the school children from industrial areas and non-industrial areas are presented in Figure 2. The mean concentrations of lead in the urine samples of the children from schools located close to industrial areas and in non-industrial areas were $0.64 \mathrm{mg} / \mathrm{L}$ and $0.46 \mathrm{mg} / \mathrm{L}$, respectively. The mean concentrations of zinc in the urine samples of the children in industrial areas and non-in- dustrial areas were $0.56 \mathrm{mg} / \mathrm{L}$ and $0.83 \mathrm{mg} / \mathrm{L}$, respectively. The mean concentrations of iron in urine samples of children from the schools located in industrial areas and non-industrial areas were $1.75 \mathrm{mg} / \mathrm{L}$ and $2.45 \mathrm{mg} / \mathrm{L}$, respectively. Copper was found in the urine samples of pupils in industrial areas with a mean concentration of $0.03 \mathrm{mg} / \mathrm{L}$, but it was not detected in any of the samples from the non-industrial areas. 


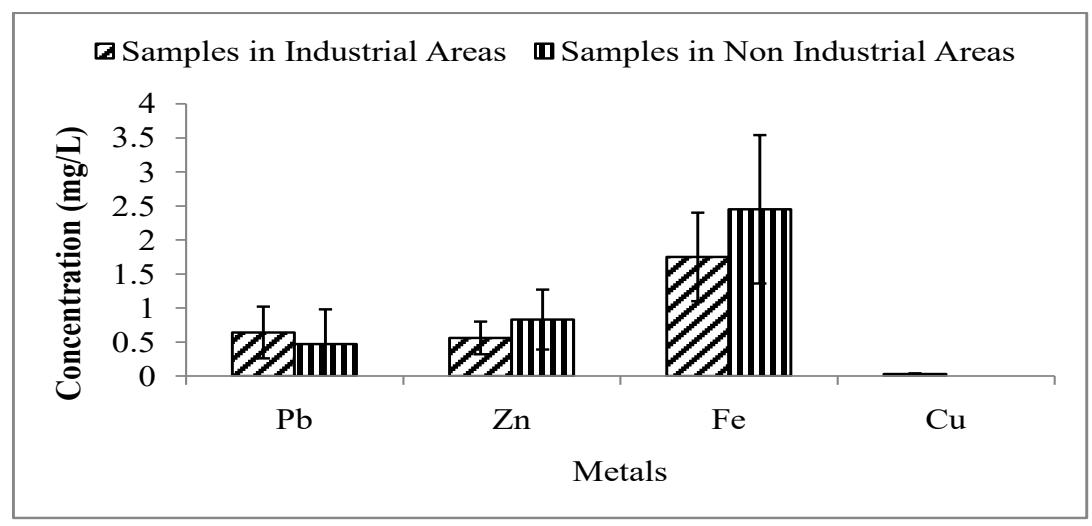

Figure 2. Mean concentrations of heavy metals in urine samples from the selected industrial and non-industrial areas: Error bars indicate standard deviations.

\section{Discussion}

Generally, the results showed that the mean concentrations of iron were higher than the mean concentrations of lead, zinc and copper. The highest concentrations of the heavy metals were obtained in samples from Bunju A (lead, iron and zinc) and Chang'ombe (lead and copper) while the lowest concentrations were from Bunju B (lead) and Mtakuja (iron and zinc). Bunju A school is located very close to the main road (within $100 \mathrm{~m}$ to $150 \mathrm{~m}$ from the main road); the high levels of the heavy metals in samples from that site may be partly due to emissions from particles and dust. Chang'ombe is located close to the industrial areas and main roads which could be among the sources of emissions and exposure. There are many factories that are located in the industrial areas in Dar es Salaam, including textile mills, brewery industries, cigarette manufacturing company, and industries engaged in fabrication and metal works. These industries could be among the important sources of heavy metal contamination in the nearby areas. The low levels of trace metal elements in the urine samples from Bunju B could be that it is located far away from the point sources. The low levels of iron and zinc in the urine samples from Mtakuja school could be explained by the fact that the school was somehow separated from the point sources/areas with major sources of metal contamination and may be the pupils' residences were generally separated from such areas.

Statistical analysis showed that there was a significant difference in the concentrations of lead in the urine samples between pupils in industrial areas and those in non-industrial areas $(t=3.130$ at 238 degrees of freedom, $p$
$<0.002)$. This implied that the concentrations of lead in urine samples were higher in the samples from the industrial areas than in samples from the non-industrial areas suggesting that the industrial activities taking place around the areas surrounding the schools and residential areas contribute significantly to the lead emissions and exposure. Emissions from the cars and tear and wear of machine parts could also increase lead exposure in addition to the exposure through food, water, air and soil.

The results showed that the concentrations of zinc and iron were higher in the urine samples of children from the non-industrial areas than in the urine samples of children from the industrial areas. The statistical analysis revealed significant differences in the mean concentrations of zinc and iron in the urine samples of pupils between the industrial and non-industrial areas (zinc: $\mathrm{t}=5.877$ at 238 degrees of freedom, $\mathrm{p}<0.0001$ and iron: $\mathrm{t}=6.058$ at 238 degrees of freedom, $\mathrm{p}<0.0001)$. Hence, the concentrations of zinc and iron in children urine samples were higher in the samples from the non-industrial areas than in the samples from the industrial areas. The reasons for these variations in zinc and iron concentrations between the two areas might be due to different contributions by inhalation of dusts and ingestion of contaminated food and water as well as other anthropogenic sources such as domestic (household) activities, commercial activities (e.g. mining activities), and waste depositions. Metals such as lead, zinc and iron are found in food substances, water, air, soil and other matrices ${ }^{7,14}$. Also, since the sites are located in urban areas, the metal emissions from different sources such as emissions from cars and particulates (dusts) might increase metal emissions in some areas and 
contribute to the variations in the levels of the heavy metals in the samples from such areas. For instance, Bunju A school is located very close to the main road and there was no water supply at that school. The detection of copper in the pupils' urine samples in the industrial areas could be related to exposure due to industrial sources and other sources, including dietary sources.

Most environmental contamination and human exposure to metals such as lead, iron and zinc are due to anthropogenic activities such as mining, smelting operations, and various uses of metals and metal-containing compounds. Therefore, the primary anthropogenic sources of the metals in the environment are related to transportation, mining, metallurgical and other industrial operations and the use of commercial products containing the metals. The metals are also found in drinking water, food and air ${ }^{18,19,20}$. Moreover, children's hand-to-mouth behaviour results in swallowing metal-containing objects, such as contaminated soil or dust.

The concentrations of the heavy metals found in this study are compared with the findings of similar studies in other countries as summarised in Table 2. The concentrations of lead found in the urine samples in the present study were greater than the concentrations of lead found in the urine of mine workers and non-miners in Ghana ${ }^{16}$, in urine of school children from urban and rural areas in Swaziland ${ }^{21}$, in urine samples of electronic repairers in Nigeria ${ }^{22}$ and in human urine after strenuous exercise in China ${ }^{23}$. The concentrations of lead in the urine samples were lower than the concentrations of lead found in the urine samples from people of various age groups in the industrial areas of Kattedan, India ${ }^{24}$ and in urine samples of children with autistic disorders and those without medical disorders in $\mathrm{Egypt}^{25}$. The concentrations of zinc found in the present study were lower than the concentrations of zinc found in the urine samples in the industrial area of Kattedan, India ${ }^{24}$ and in the urine samples of children in the Czech Republic ${ }^{26}$, but were greater than the concentrations of zinc found in urine samples after strenuous exercise in China ${ }^{23}$. The concentrations of copper found in the urine samples in the present study were lower than the levels found in the urine samples in China, India and the Czech Republic ${ }^{23,24,26}$. Cadmium was detected in the studies in Ghana, Nigeria, China, India and Egypt ${ }^{16,22,23,24,25}$.

The findings of the present study on lead differ from those reported in Nigeria by Esimai and Awotoye ${ }^{27}$ who found that there was no significant difference in the concentrations of lead in urine of children between those living in industrial areas (urban areas) and rural non-industrial areas of Osun State. The findings of this study for zinc differ from the findings reported in Spain by Schuhmacher et $a .^{28}$, who found that there was no significant difference in the concentrations of zinc in the urine samples of children living in industrial and rural-non industrial areas. No study was identified in literature for comparison of the concentrations of iron in the urine samples of children in the industrial areas and non-industrial areas. Considering the toxic effects of lead, the concentrations of this metal found in the urine samples in the present study could indicate potential health risks to the children. The concentrations of iron found in this study were generally low and could not be expected to indicate toxic effects. Toxic effects of iron in human beings begin to occur at ingestion doses of above $10-20 \mathrm{mg} / \mathrm{kg}$ of elemental iron ${ }^{29}$. The low concentrations of zinc and copper found in the samples could not indicate health risks. 
Table 2. Comparison of the concentrations of heavy metals in urine with data in previous studies.

\begin{tabular}{|c|c|c|c|c|c|c|c|c|}
\hline Location & Samples & \multirow{2}{*}{$\begin{array}{l}\text { Lead } \\
0.017 \text { to } 0.040 \\
\mathrm{mg} / \mathrm{L}\end{array}$} & \multirow{2}{*}{$\begin{array}{l}\text { Zinc } \\
\text { NA }\end{array}$} & \multirow{2}{*}{$\begin{array}{l}\text { Iron } \\
\text { NA }\end{array}$} & \multicolumn{2}{|l|}{ Copper } & Cadmium & References \\
\hline $\begin{array}{l}\text { Swaziland, } \\
\text { urban and } \\
\text { rural areas }\end{array}$ & $\begin{array}{l}\text { Urine, } \\
\text { children }\end{array}$ & & & & \multicolumn{2}{|l|}{ NA } & NA & $\begin{array}{l}\text { Okonkwo } \\
\text { et al. }\end{array}$ \\
\hline Nigeria & $\begin{array}{l}\text { Urine, electronic } \\
\text { repairers }\end{array}$ & $\begin{array}{l}0.2418 \quad \pm \\
0.0298 \mathrm{mg} / \mathrm{L}\end{array}$ & NA & NA & \multicolumn{2}{|l|}{ NA } & $\begin{array}{l}0.0681 \\
0.1005 \\
\mathrm{mg} / \mathrm{L}\end{array}$ & Lawal $^{22}$ \\
\hline China & $\begin{array}{l}\text { Human urine } \\
\text { after strenuous } \\
\text { exercise }\end{array}$ & $\begin{array}{l}0.03 \pm 0.001 \\
\mu \mathrm{g} / \mathrm{L}\end{array}$ & $\begin{array}{l}0.81 \pm \\
0.013 \\
\mu g / \mathrm{L}\end{array}$ & NA & \multicolumn{2}{|c|}{$\begin{array}{l}0.18 \pm 0.003 \\
\mu \mathrm{g} / \mathrm{L}\end{array}$} & $\begin{array}{l}0.001 \\
0.0007 \\
\mu g / \mathrm{L}\end{array}$ & $\begin{array}{l}\text { Tang } \\
\text { et al. }{ }^{23}\end{array}$ \\
\hline $\begin{array}{l}\text { India, } \\
\text { industrial } \\
\text { areas of } \\
\text { Kattedan }\end{array}$ & $\begin{array}{l}\text { Urine, people of } \\
\text { various age } \\
\text { groups }\end{array}$ & $\begin{array}{l}60 \text { to } 180 \\
\mu \mathrm{g} / \mathrm{g}\end{array}$ & $\begin{array}{l}100 \text { to } \\
660 \mu \mathrm{g} / \mathrm{g}\end{array}$ & NA & $\begin{array}{l}27.1 \quad \text { to } \\
\mu \mathrm{g} / \mathrm{g}\end{array}$ & 115 & $\begin{array}{l}10 \text { to } 40 \\
\mu \mathrm{g} / \mathrm{L}\end{array}$ & $\begin{array}{l}\text { Sekhar } \\
\text { et al. }{ }^{24}\end{array}$ \\
\hline $\begin{array}{l}\text { Czech } \\
\text { Republic }\end{array}$ & $\begin{array}{l}\text { Urine } \\
\text { children }\end{array}$ & $\begin{array}{l}\text { Median } \quad 4.8 \\
\mu \mathrm{g} / \mathrm{g} \\
\text { creatinine }\end{array}$ & $\begin{array}{l}\text { Median } \\
460 \mu \mathrm{g} / \mathrm{g} \\
\text { creatinine }\end{array}$ & NA & $\begin{array}{l}\text { Median } \\
\mu \mathrm{g} / \mathrm{g} \\
\text { creatinine }\end{array}$ & 16.1 & $\begin{array}{l}\text { Median } \\
0.29 \mu \mathrm{g} / \mathrm{g} \\
\text { creatinine }\end{array}$ & $\begin{array}{l}\text { Benes } \\
\text { et al. }{ }^{26}\end{array}$ \\
\hline $\begin{array}{l}\text { Ghana, } \\
\text { Golden Star } \\
\text { Bogoso } \\
\text { mines, Cape } \\
\text { Coast }\end{array}$ & $\begin{array}{l}\text { Urine, mine } \\
\text { workers and } \\
\text { non-miners } \\
\text { (students) }\end{array}$ & $\begin{array}{l}\text { Mean } 0.2912 \\
\pm 0.08335 \\
\mathrm{mg} / \mathrm{L} \\
\text { Range } 0.0008 \\
\text { to } 0.492 \\
\mathrm{mg} / \mathrm{L}\end{array}$ & NA & NA & NA & & $\begin{array}{l}\text { ND in mine } \\
\text { workers; } \\
0.0083 \pm \\
0.00127 \\
\mathrm{mg} / \mathrm{L} \text { in } \\
\text { non-miners }\end{array}$ & $\begin{array}{l}\text { Adotey } \\
\text { et al. }{ }^{16}\end{array}$ \\
\hline Egypt & $\begin{array}{l}\text { Urine, children } \\
\text { with autistic } \\
\text { disorder } \\
\text { Urine, children } \\
\text { without medical } \\
\text { disorders } \\
\text { (control group) }\end{array}$ & $\begin{array}{l}8.45 \pm 7.33 \\
\mu \mathrm{g} / \mathrm{g} \\
3.36 \pm 4.11 \\
\mu \mathrm{g} / \mathrm{g}(\mathrm{mg} / \mathrm{kg})\end{array}$ & NA & NA & NA & & $\begin{array}{l}0.41 \pm 0.26 \\
\mu \mathrm{g} / \mathrm{g} \\
0.53 \pm 0.38 \\
\mu \mathrm{g} / \mathrm{g} \\
(\mathrm{mg} / \mathrm{kg})\end{array}$ & $\begin{array}{l}\text { Blaurock- } \\
\text { Busch } \\
\text { et al. }{ }^{25}\end{array}$ \\
\hline $\begin{array}{l}\text { Tanzania, } \\
\text { industrial } \\
\text { and non- } \\
\text { industrial } \\
\text { areas in Dar } \\
\text { es Salaam }\end{array}$ & $\begin{array}{l}\text { Urine, primary } \\
\text { school children }\end{array}$ & $\begin{array}{l}0.55 \pm 0.46 \\
\mathrm{mg} / \mathrm{L} \\
\mathrm{Max} \\
\mathrm{mg} / \mathrm{L}\end{array}$ & $\begin{array}{l}0.69 \quad \pm \\
0.38 \\
\mathrm{mg} / \mathrm{L} \\
\mathrm{Max} 2.55 \\
\mathrm{mg} / \mathrm{L}\end{array}$ & $\begin{array}{l}2.10 \\
\pm \\
0.97 \\
\mathrm{mg} / \mathrm{L} \\
\mathrm{Max} \\
8.98 \\
\mathrm{mg} / \mathrm{L}\end{array}$ & $\begin{array}{l}0.01 \pm \\
\mathrm{mg} / \mathrm{L} \\
\mathrm{Max} \\
\mathrm{mg} / \mathrm{L}\end{array}$ & $\begin{array}{l}0.02 \\
0.05\end{array}$ & ND & This study \\
\hline
\end{tabular}

\section{Conclusion}

The concentrations of lead and copper in urine were higher in the samples from the industrial areas than those from the non-industrial areas, and this could be related to the industrial activities taking place around the areas. The concentrations of zinc and iron in urine were higher in samples from the non-industrial areas than from the industrial areas. This implied that there were other significant sources of these metals in non-industrial areas. There were significant differences in the concentrations of the heavy metals in pupils' urine samples between the industrial areas and non-industrial areas. This might be related to the differences in exposure from various sources such as industrial activities, water, food and soil. The levels of contamination due to lead could indicate potential health risks to the children, but the concentrations of iron, zinc and copper were generally low and could not indicate health risks.

\section{Conflicts of interest}

The authors declare that there are no conflicts of interest regarding the publication of this manuscript. 


\section{Acknowledgements}

The authors sincerely appreciate the Muslim University of Morogoro for supporting this study. We are grateful to Dr. F Sung'hwa and Mr. M Mayuni of the Chemistry Department, University of Dar es Salaam for technical assistance.

\section{References}

1. Kim YH, Shin SK, Han JS, Song KB, Lee SY, Hong EJ, Park JJ. Studies of heavy metal analytical methods for human urine using inductively coupled plasma-mass spectroscopy. Epidemiology. 2011; 22: 31-154.

2. Tsalev L, Zaprianov Z (Eds). Atomic absorption spectrometry in occupational and environmental health monitoring. CRC Press, Boca Raton, FL, 1988.

3. Clarkson TW, Magos L. The toxicology of mercury and its chemical compounds. Critical Reviews in Toxicology. 2006; 36: 609-662.

4. Olsen J. Prenatal exposures and long-term health effects. Epidemiologic Reviews. 2000; 22: 76-81.

5. Schwartz J. Air pollution and children's health. Pediatrics. 2004; 113: 1037-1043.

6. AguileraI, Daponte A, Gil F, Hernández A, Godoy A, Pla A, Ramos JL, DASAHU group, Fernandez-Ajulia A, Toro S, Martin-Olmedo P, Lacasana M, Mayoral JM, Villanueva L, de Santiago E, Lopez O, Sanchez-Parra F. Urinary levels of arsenic and heavy metals in children and adolescents living in the industrialised area of Ria of Huelva (SW Spain). Environment International. 2010; 36: 563-569.

7. Morais S, Costa FG, Pereira ML. Heavy Metals and Human Health. In: Oosthuizen J (Ed), Environmental health-Emerging Issues and Practice, InTech 2012; ch. 10: 227-246.

8. WHO (World Health Organization). Lead Poisoning and Health Fact Sheet. WHO, 2017.

9. Schoeters G, Den Hond E, Zuurbier M, Naginiene R, van den Hazel P, Stilianakis N, Ronchetti R, Koppe JG. Cadmium and children: Exposure and health effects. Acta Pcediatrica. 2006; 95 Suppl 453: 50-54.

10. Plum LM, Rink L, Haase H. The essential toxin: impact of zinc on human health. International Journal of Environmental Research and Public Health. 2010; 7(4): 1342-65.

11. Agency for Toxic Substances and Disease Registry (ATSDR). Toxicological Profile for Copper. Atlanta, GA: U.S. Department of Health and Human Services, Public Health Service, 2004.
12. Valentine K, Mastropietro C, Sarnaik AP. Infantile iron poisoning: Challenges in diagnosis and management. Pediatric Critical Care Medicine. 2009; 10(3): e31-e33.

13. Kihampa C, Mwegoha WJ, Shemdoe RS. Heavy metals concentrations in vegetables grown in the vicinity of the closed dumpsite. International Journal of Environmental Sciences. 2011; 2: 889-895.

14. Mohammed NK, Khamis FO. Assessment of heavy metal contamination in vegetables consumed in Zanzibar. Natural Science. 2012; 4: 588-594.

15. Mrutu A, Nkotagu HH, Luilo GB. Spatial distribution of heavy metals in Msimbazi River mangrove sediments in Dar es Salaam coastal zone, Tanzania. International Journal of Environmental Sciences. 2013; 3: 1641-1655.

16. Adotey JP, Bentum JK, Koranteng-Addo EJ, Baah FK. Comparative studies of some heavy metals in the urine of people engaged in mining and non-miners. Journal of Chemical and Pharmaceutical Research. 2011; 3: 148153.

17. Zolotov YA, Kuzmin NM. Preconcentration of Trace Elements, Elsevier, Amsterdam, 1990.

18. Allen LH. Iron supplements: scientific issues concerning efficacy and implications for research and programs. The Journal of Nutrition. 2002; 132: 813S-819S.

19. ATSDR. Toxicological Profile for Zinc. Atlanta, GA: U.S. Department of Health and Human Services, Public Health Service, 2005.

20. Warmate AG, Ideriah TJK, Tamunobereton IT, Inyang UEU, Ibaraye T. Concentrations of heavy metals in soil and water receiving used engine oil in Port Harcourt, Nigeria. Journal of Ecology and the Natural Environment. 2011; 3: 54-57.

21. Okonkwo JO, Lwenje SM, Mtetwa VS, Gumedze PN, Shilongonyane MM. Determination of urinary lead in school children in Manzini, Swaziland, Southern Africa. The Enviromentalist. 2001; 21: 205-209.

22. Lawal M. Levels of lead, cadmium and chromium in blood, urine, nail and hair samples of electronic repairers in Kaduna Metropolis, Nigeria. PhD Dissertation, Ahmadu Bello University, Zaria, 2014.

23. Tang SX, Yu XZ, Wu CN. Comparison of the levels of five heavy metals in human urine and sweat after strenuous exercise by ICP-MS. Journal of Applied Mathematics and Physics. 2016; 4: 183-188.

24. Sekhar KC, Chary NS, Kamala CT, Vairamani M, Anjaneyulu Y, Balaram V, Sorlie JE. Environmental risk assessment studies of heavy metal contamination in the 
industrial area of Kattedan, India-a case study. Human and Ecological Risk Assessment. 2006; 12: 408-422.

25. Blaurock-Busch E, Amin OR, Rabah T. Heavy metals and trace elements in hair and urine of a sample of Arab children with autistic spectrum disorder. Madica. 2011; 6: 247-257.

26. Benes B, Spěvácková V, Smíd J, Cejchanová M, Kaplanová E, Cerná M, Gajewská V, Blatný J. Determination of normal concentration levels of $\mathrm{Cd}, \mathrm{Pb}, \mathrm{Hg}, \mathrm{Cu}, \mathrm{Zn}$ and Se in urine of the population in the Czech Republic. Central European Journal of Public Health. 2002; 10: 3-5.
27. Esimai OA, Awotoye OO. Estimation of lead in urine of school children in South Western Nigeria and effect of ascorbic intervention. African Journal of Environmental Science and Technology. 2009; 3: 370-375.

28. Schuhmacher M, Domingo JL, Corbella J. Zinc and copper levels in serum and urine: relationship to biologi$\mathrm{cal}$, habitual and environmental factors. Science of the Total Environment. 1994; 148: 67-72.

29. Webmd.com. Iron Poisoning. https://www.webmd. com/a-to-z-guides/iron-poisoning\#1 Retrieved $23^{\text {rd }}$ May 2018. 